\title{
Social Representations of Heroes: Triggers from the Past, Values in the Present, Patterns for the Future
}

\author{
Sára Bigazzi ${ }^{1} \cdot$ Fanni Csernus $^{1} \cdot$ Anna Siegler $^{1}$ (ID) $\cdot$ Ildikó Bokrétás $^{1} \cdot$ Sára Serdült $^{1}$. \\ Izabella Ilea ${ }^{1} \cdot$ Afroditi Giourga $^{1} \cdot$ Melike Kahraman ${ }^{1} \cdot$ Bálint Takács $^{1}$
}

Received: 30 May 2021 / Revised: 1 September 2021 / Accepted: 3 September 2021

(c) The Author(s) 2021

\begin{abstract}
The representations of heroes and the heroic acts point to social values, norms, and morality of the present, creating a bridge between the past and a potential future. In this paper, a cross-cultural explorative study of heroes is presented aiming to explore general tendencies and possible patterns related to the different social contexts. Participants were reached from seven countries via social media $(N=974)$ for corpus construction. We asked by their choice of hero, national hero, and desired heroic action in their respective countries. A thematic analysis was conducted. Results show that there is a high rate of no choice, while among the chosen the prototypical hero is a lone moral man acting in the private (family) or public sphere (political actors). Both spheres offer the naturalization of the hero. There is a dialogical frame between the exceptional and the ordinary. Chosen heroes are dominantly contemporary males' family members or political figures. While the purpose attributed to the personal hero is to maintain stability, the purpose attributed to the heroic actions of the public sphere is to obtain change. Similarities and differences between the seven subcorpuses are also described.
\end{abstract}

Keywords Hero $\cdot$ Social representations $\cdot$ Values $\cdot$ Heroic action $\cdot$ Collective actions

From a social-psychological perspective, the increasing freedom followed by the economic crisis caused uncertainty of the last decades created space for collective anxieties. The spread of right-wing populism-creating differences both horizontally and vertically, ignores knowledge and elite, degrades institutions, creates common enemies for the nation to justify itself (Staerklé \& Green, 2018) as a morally superior group of "ordinary people" (Mols \& Jetten, 2016; Mudde, 2004; Vossen, 2010)—can be seen as the political sphere's answer to the "social demand" for feelings of safety and order while giving easily accessible form to fears stemming from otherwise elusive and complex social-economic problems. While refugees, ethnic minorities, other vulnerable social groups (LGBTQ, women) are targeted as scape-goats of societal problems, a renewal of

Anna Siegler

siegler.anna@pte.hu

1 Department of Psychology, University of Pécs, Pécs, Hungary 
human-rights movements and civil action is also on the rise. There is a strong ideological struggle (Jovchelovitch, 1997) to cope with the social and economic uncertainty of nowadays. While people have similar normative reference frames of knowledge (about social reality, values, identity, ideologies) which permits communication, their positioning on it is pluralistic, to create consent or dissent (Staerklé, 2011, 2013). There is a crescent antagonism of reference frames about social reality as responding to "threat, people may refer to such knowledge in order to interpret the threatening situation and to take action on the basis of culturally available strategies and discursive resources" (Staerklé, 2011:89) between the demand of highly structured social order with authoritarian leaders, secure structure, definite norms, traditional values, stable borders which competes with more dynamic demands of social order. In the last decades, a new split arises and become more and more visible between these more dynamic social orders: la realité de liberté (Charrue, 2005)—based on the norms of self-interest, free will, autonomy, individual responsibility, and self-regulating economy and the la realité de fraternité-based on the norms of horizontal democratic processes, interdependence, solidarity, cooperation, the experiencing and managing diversity for an equitable, and inclusive society (Brown, 2011; Graham, 1992; Hepburn, 2003). People anchored to these different norms are seeking for ideals, moral compasses, heroes to look up to and follow their lead in congruence to their own reference frame. In this paper, we look at how different cultural contexts emphasize different aspects of heroic representations and what can we infer from these regarding the social norms, values, and participatory intentions in different collective action.

\section{Choosing Heroes}

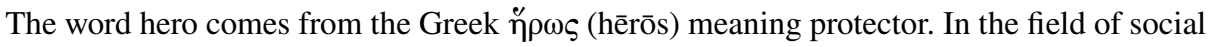
psychology, heroes are a relatively understudied area, which has attracted growing interest over the past decades. The relevant literature offers diverse conceptualizations of a hero, each focusing on a different aspect, such as someone with a moral will, doing good for others (Schwartz, 2012); one who makes sacrifices for others in their community (Becker \& Eagly, 2004); one protecting and helping the well-being of future generations (Gash \& Conway, 1997; Kinsella et al., 2017); one who refuses to conform to unjust norms and does not obey to unfair authorities (Zimbardo, 2008); and one who persists even when facing obstacles or failures (Halmburger et al., 2017). Heroes can be divided into small and big heroism (Farley, 2012) or multiple categories of heroism (Franco et al., 2011; Goethals $\&$ Allison, 2012). While the hero in general represents the extraordinary through abstract values such as brave, self-sacrificing, strong, helpful, and everyday hero is contextualized, anchored to concrete situations of everyday life "present in Heroic Roles, Ordinary Heroism and Everyday Context" (Keczer et al., 2016:14). These theoretical definitions naturalize the hero, as being or becoming heroic is a moral choice, personality, behavior of the individual. Boulanger describe this twofolded process in his concept of CHARACTERisation (Boulanger \& Christenson, 2018; Boulanger, 2019); there is the process of translation from "the immanent and immediate life to the transcendent" and than "people invent new ways of relating with the object in the practical life constructing new needs" (Boulanger, 2019:17).

Adapting the approach of social representations, a hero is not a hero by his/her inner characteristics, but by the normative reference frame adopted by those judging him/her as a hero. The choice of a hero is embedded in the historical and social context of the one who 
judges, such as the cultural and communicative aspects of the collective memory (Assman, 2011), the dominant and alternative cultural narratives providing a context for heroic characters and actions (László, 2013), the accepted and contested norms, and the system of competing values (Jayawickreme \& Di Stefano, 2012; Kinsella et al., 2015) as the existence or emergence of counter-normative sources of active minorities in dialogical relation with the majorities (Markova, 2011).

\section{Value Permeated Dialogical Knowledge}

As Allison and Goethals (2014) point out in their conceptualization of the Heroic Leadership Dynamic, narratives about heroes offer psychological benefits. These characters can fulfill cognitive and emotional needs by providing wisdom, meaning, hope, inspiration, and growth. As these needs are unstable and change over time, the choices of heroes also change depending on the individual's developmental stage and current life situation (Allison \& Goethals, 2014).

The dynamic evolution of the heroic image does not only depend on individual change and circumstances. Since the concept of hero is value-based (Jayawickreme \& Di Stefano, 2012) and radically ambivalent (Csikszentmihalyi et al., 2017; Franco et al., 2011), it implicitly defines what is considered good and bad in the present society. However, the meaning of good/bad, unjust/just, at a social level changes over time, and it is continuously negotiated between parties or imposed by those with power upon communication fields. As Foucault points out in his debate with Chomsky on human nature (1971) that justice is "an idea invented and applied in different types of society as an instrument of a certain political and economic power, or as a weapon against this power" (Chomsky \& Foucault, 2015:69). The inherent ambivalence of the hero belongs to the continuously changing intersection between the concrete (heroic) "action" and the contextual features of what is considered good or bad. In this intersection, the potential interpretations of the "action" can forge the heroic interpretations. These potential interpretations of the hero are grounded into the value system of the position of those individuals and groups which participate in these direct (about the hero) and indirect (about values) negotiation processes. For this reason, the "creation" of a hero, as a moral character embedded in a narrative, is a prospective and retrospective process at the same time, orients the future, stabilizes the present, and reinterprets the past.

Moscovici abandons the durkheimian collective representation as too much static and normatively coercive and adopts a more dynamic approach not just because of the different belongings of the individual in modern societies, but also to take into account "the representational diversity, tension and even conflict in modern life" (Rose et al., 1995:3). Moscovici (1988) distinguished among the coercive and widely consensual hegemonic, the differentiated but not incompatible emancipated and the conflict or tension based polemical representations. In this way, social representational fields does not construct a fully consensual reifying universe, the degree of consensuality, which permits to understand each other, reflects the power of social reality upon the individuals, while there is the agency of the individuals, or (active) minorities to question that reality or act for change. Representational diversity, ambivalent thoughts, inconsistent ideas, and tension are embedded in the very structure of social representations. This cognitive polyphasia reflects both how knowledge is intrinsically bound to communities and social contexts, thus changing social conditions knowledge changes as well (Moscovici, 1961/2008; 
Jovchelovitch, 2002, 2007), and the agency of the individuals to act in a context with competing representations, which means also the ability to adapt or to resist to social change (Batel, 2012).

Societies and communities offer identifications to the individuals (Elcheroth et al., 2011; Tajfel, 1981); these belongings as anchoring points become the interpretative lens of the world around (Breakwell, 2001; Jovchelovitch, 1997; Lloyd \& Duveen, 1991; Wagner, 1998). A few of these socially constructed categories, like nation (Anderson, 1991; Reicher \& Hopkins, 2001) and gender (Duveen \& Lloyd, 1986), class (Elcheroth, 2006), can become relevant in specific times even through identity politics offering a wide range of representations to their members (Dogra, 2012; Howart et al., 2014). For example, a glorifying national identity not only offer a glorious re-interpretation of the past and the role of collective victimhood (Bar-Tal et al, 2009; Rimé et al., 2015; László, 2013) or the perception of the different outgroups and minorities as threatening the unity of the nation (Cohen, 1979; Elcheroth \& Spini, 2011), but also how this position thinks about gender, religion, or not thinks about class differences. Thus, identities and representational fields are strictly interwoven, more possibilities have the individuals to belong and act, more an internal dialogical work among the different roles, and their respective representational fields will arise to diminish incongruencies.

Behind the construction of heroic narratives, we find embedded morality, norms, and values of the present. Values are concepts of the desirable ways of action, which serve as cross-situational guiding principles (Ingelhart, 2000; Schwartz, 2012). Furthermore, values provide standards and criteria for the evaluation of actions and their consequences, for the justification of opinions, and they are guidelines for possible behaviors, interactions, decisions, and interpretations of the self and others (Bigazzi \& Nencini, 2008). Yet, according to social representation theory, values and morality are not separated entities, but each knowledge that groups and societies accumulated in and through culture over generations are value-loaded (Markova, 2017:363), as Moscovici states arguing on specific about Human Sciences, in general about societies, by "ascribing a value to each of the possibilities perceived" people create a reference framework, "by which all else is judged" (Moscivici, 1993:362). Thus, the theory looks at the human as an "ethical being" (Markova, 2013) and question the idea of a superior and inferior knowledge permeated in human and social sciences, according to which there is a superior knowledge based on facts, science, and logics, and an inferior one based on imagination, values, and believes. These distinctions between facts and values construct an idea of neutrality and neglect the ethical choices of scientific questions as well.

\section{The Potential of Heroes on Action}

According to the theory of social representations, two processes-anchoring and objectification-underlie the emergence of new social objects that represent something previously unknown or unfamiliar. Anchoring relates the unknown to existing knowledgeinserting it "into a hierarchy of values and into its operation" (Moscovici, 1961/2008:104). Objectification is the process as a result of which the "invisible" becomes "perceptible" (Farr, 1984: 386), or something that is abstract becomes material and concrete, "integrated into social reality" (Moscovici, 1961/2008:106, 1984; Farr, 1984; Abric, 1996; Billig, 1988). 
We assume that individuals' choices of their heroes objectify their value systems and its potentialities for the future, thus they use the past, reconstructing it according to move forward the ethically chosen potential future. In this way, heroes as role models offer to the individual's potential behaviors to imitate. Imitation process from an ontogenetic perspective - that of persistent imitation (Baldwin, 1894), by copying constructively experimenting and reproducing into a novel form — creates the zone of proximal development (Vygotsky, 1933/1984 in Valsiner \& van der Veer, 1993), where the child participating to joint activities of still comfortable but challenging tasks, and with the socially constructed constraints and supports reflected by the socially available others explores the potentially near future (Rogoff, 2003). Valsiner concept of zones (1987) proposes the intersection between the constraining and supporting context and the individual as free as possible activity in it. The "bounded indeterminacy" of transition from the present to the next future includes potentials that will or will not become (Valsiner, 1997; Valsiner \& van der Veer, 1993). The implicit ambivalence of heroic choices inherently holds these potentials of becoming from the present to the future through creative imitation of past figures, moral exemplars. The concept of time is relevant here and concerns two of the four layers defined by Tateo and Valsiner (2015). At a psychological level, time is understood as irreversible, shared, and communicated at intersubjective level, leading to a coordination that becomes socially constraining. This irreversible time justify the heroic choice coming from the past. However, time is also a cultural construct here, containing shared historical heritage and historical characters that constitutes the context of future experiences (Tateo \& Valsiner, 2015:360). The stories about heroes serve the social representations of moral codes; thus, they justify potential actions while inhibiting others. Their specific story is re-interpreted in the holder's mind, however, bounding the quality of potential future actions.

Meanwhile, for some individuals, the hero is activating, serves as a moral example to imitate in a creative way, we assume that for others heroes can be passivating as well. In these cases, individuals can outsource the moral commitment and responsibility to the hero, he or she still sacrificed her/himself to the cause, with or without obtaining results, but the price, the sacrifice was enough. In these cases, probably the (social) cause or the action interpreted as more futile, there is nothing worse that much. Another case of passivating heroic representation, when the heroic act is assumed to be accomplished because of the supreme and unachievable inner and innate qualities of the hero, with an implicit comparison and too much psychological distance, or superiority of the heroic figure leading to block the imitation process. The same psychological distancing is assumed when people choose heroes from distant contexts, for example, from a remote past, not from the ambivalence and moral choices of the more recent communicative memories, but from the dominant and institutionalized representations of cultural memories (Assman, 2011). As Assman states, the remote past is "highly formalized and institutionalized" by specialists and power (Assman, 2011:18), similar to the Durkheiman concept of collective or to Moscovici's hegemonic representations. As these memories are less debated and diffused, they allow less possibilities of interpretation and inner tension. To choose a hero from the remote past, without that tension and ambivalence, can be seen as a moral disengagement, or a choice of neutrality and leaving out present moral dilemmas (Touraine, 1985; Turner \& Hamilton, 1994).

The Heroic Imagination Project, led by Zimbardo, encourages ordinary people of all nationalities and ages to commit acts of heroism. Zimbardo points out the potentially heroic quality of passivity as well: "we often think of heroics as a valiant activity, something that is clearly observable. But some forms of heroism involve passive resistance or an unwillingness to be moved" (Franco \& Zimbardo, 2006:32). Thus, between potential 
actions based on heroes, we can identify passivity as well, as the action itself of opposing, not acting as expected. As potential actions, potential passivities can also be offered by the choice of the figure of a hero.

\section{Heroic Actions as Narratives}

Narratives (Bruner, 2004) are social constructions relating historical events to current ones, at the same time report the collective experiences of a community, embody values and belief-systems, and represent the shared identity of the collective. Heroic actions are represented in schematic narratives which include a goal and a plan (the moral will), a performed action, the cost to pay for pursuing the specific goal (sacrifice), and the outcome of that action (Bar-Tal et al., 2009; Čehajić-Clancy \& Bilewicz, 2017; Labov, 2010). The specific part on which the narrator focuses gives account of the narrator's present state and potential performance (Bruner, 2004; László et al., 2013; Liu \& László, 2007). According to the narrative social psychology (László, 2013; Murray, 2017), the collective experiences behind the moral order of societies and groups are organized in narrative structures; thus, the social identities of the individuals and the culturally available heroic narratives create differences in the potential directions of action in the social arena. While thinking about moral actions, focusing on the plans or the actions and outcomes rather than on the potential barriers and costs creates cognitive perspective for potentialities and stimulates action out of the ordinary. As Collins states, "there are classes of behavior that escapes from cost/benefit analysis. These include emotional behavior, altruism, and morally or value-motivated behavior generally" (Collins, 1993:203), instead of being rational decision-makers, individuals tend to focus on those information that underline their own position and motivation (Collins, 1993). When individuals describe an action as heroic, taking the perspective, the values, the motivation of the hero, or his/her actions or the achieved results they are more willing to activate similar actions, while when they create the heroic of the action through the sacrifices. Focusing on the cost/benefits of an action belongs to the decision-making of the rational man model, while individuals are more able to engage in actions of bravery when they do not focus on possible obstacles and barriers.

Neither social movements nor heroic actions, due to their dialogical nature, are always aimed at changing the political system or struggling against the prevailing social norms; they can also serve the prevailing social order with its values, norms, and ideologies. These latter actions serve restorative and protective purposes rather than innovation (Yadav, 2015). Questioning the existent normative system, due to the rise of cognitive alternatives based on the perception of the social system as unjust and/or unstable, enables the development of movements aimed at changing the current political and social order (Tajfel, 1981). However, participation in such movements not only includes the expression of alternative views on social order but also the engagement in the symbolic struggle for power, in which these particular views must overcome others (Bigazzi et al., 2019; Howarth et al., 2014; Jovchelovitch, 1997).

The last decades, we see the spread of collective actions and changes in its regulation (Nagy, 2019), the strengthening of participation to the social arena and to the communities, while there is also a strong polarization (Campbell, 2006, Down \& Wilson 2008; Baldassarri \& Park, 2020) all around the world fueled by identity politics (Mintchev $\&$ Moore, 2019; Tsatsanis et al., 2020; McNeil-Willson et al., 2019). Manifest is the 
dialogical nature of value based knowledge related to dynamic identifications and available representations in the context, information becomes fake news between social network bubbles, and values tried to be re- and renegotiated on the surface, values concerning nature-human relation, ways of co-living, boundaries, leadership, etc. As heroes are figures from the past reinterpreted according to moral positions of the present with the aim to create potential actions in the future, their explorative analysis can highlight the persistent ethical dilemmas and potential future actions in their context.

\section{Method}

\section{Sample}

Data were collected from 974 participants recruited with convenience sampling online in 2019. We chose European countries divergent in relation to the eight units based on traditional/secular and survival/self-expression values described by the cultural map of the world value survey of Inglehart-Welzel World Cultural Map (2020): from Orthodox Europe unit Greece $(N=106)$; from the Catholic Europe unit Italy $(N=103)$, Hungary $(N=215)$, France $(N=178)$; from the Protestant Europe unit Germany $(N=172)$; from the English speaking unit UK $(N=115)$; and from the African-Islamic unit Turkey $(N=85)$; In the other 3 units (Latin American, Confusian, and West and South Asian), no European countries were find. 429 males and 540 females aged between 18 to 82 years $(M=34.6$,

Table 1 Subsamples

\begin{tabular}{|c|c|c|c|c|}
\hline Nationality & $N$ & $\begin{array}{l}\text { Age } \\
\boldsymbol{M}(\boldsymbol{S D})\end{array}$ & $\begin{array}{l}\text { Gender female share of } \\
\text { the sample, } \%\end{array}$ & Education \\
\hline Hungarian & 215 & $29.76(10.94)$ & 61.68 & $\begin{array}{l}29.30 \% \text { high school } \\
66.05 \% \text { university (BA, MA) } \\
2.33 \% \text { elementary school } \\
2.33 \% \text { no answer }\end{array}$ \\
\hline British & 115 & $44.53(16.03)$ & 54.87 & $\begin{array}{l}55.65 \% \text { high school } \\
42.61 \% \text { university (BA, MA) } \\
1.74 \% \text { no answer }\end{array}$ \\
\hline Greek & 106 & $32.89(12.29)$ & 45.71 & $\begin{array}{l}71.70 \% \text { high school } \\
26.42 \% \text { university (BA, MA) } \\
1.89 \% \text { elementary school }\end{array}$ \\
\hline German & 172 & $34.23(16.28)$ & 52.91 & $\begin{array}{l}63.37 \% \text { high school } \\
34.3 \% \text { university (BA, MA) } \\
2.33 \% \text { elementary school }\end{array}$ \\
\hline Italian & 103 & 38.28 (11.77) & 60.19 & $\begin{array}{l}18.45 \% \text { high school } \\
63.11 \% \text { university (BA, MA) } \\
18.45 \% \text { no answer }\end{array}$ \\
\hline French & 178 & $27.76(8.25)$ & 54.8 & $\begin{array}{l}48.88 \% \text { high school } \\
49.43 \% \text { university (BA, MA) } \\
1.12 \% \text { no answer }\end{array}$ \\
\hline Turkish & 85 & $37.55(14.46)$ & 56.47 & $\begin{array}{l}85.88 \% \text { high school } \\
14.12 \% \text { university (BA, MA) }\end{array}$ \\
\hline
\end{tabular}


$S D=14.2$ ) constituted our sample. Descriptive data of the national subsamples are summarized in Table 1.

The national subsamples differed both in size and in mean age. The French and the Hungarian subsamples were the youngest on average, while the oldest were the British, the Italians, and the Turkish. Apart from the Greek subsample, female participants were in majority in all cases.

\section{Instruments}

The online questionnaire included the following open-ended questions: (1) who is your personal hero? (personal hero) and (2) why? (personal action); (3) who is your national hero? (national hero) and (4) why? (national action); and finally (5) what do you think that a heroic act could be in your country nowadays? (desired action). The open-ended questions were followed by general demographic questions (gender, age, education).

For the open-ended questions, an inductive coding scheme was developed in team-work with the 8 researchers involved (Krippendorf, 1980; Bauer, 2000; Marks \& Yardley, 2004; Smith \& Joffe 2013, Liu et al., 2005). The coding system applied according to the purposes of a thematic analysis based on the theoretical considerations discussed. The coding process proceeded manually in team work, while each researcher involved coded into an excel sheet with the answers of one subsample (except for the Hungarian data, splitted between two researchers), ambiguity or hesitations concerning categorisations of the answers were discussed in the team. For the heroic figures (personal and national), the same codes were applied. For their explanations, as well as the desired heroic action same codes were applied (Table 2.)

\section{Thematic Analysis}

Concerning the (1) type of character (Table 2), the following codes were used both for the personal and national heroes: chosen from religion, family, fiction, sport, science, art, media, the participant himself/herself, military, healthcare, ordinary people, politics, history. The distinction between the latter two categories was chronological. The political actor code was used for contemporary actors active during the twentieth or twenty-first century, whereas heroes from an earlier period were coded as historical figures. This differentiation was based on Jan Assman's distinction between communicative and cultural memory (Assman, 2011). The heroes' (2) gender (woman or man) and (3) number (lone individual or collective actors, such as "firemen" and "nurses") were also coded.

The thematic analysis of heroic actions (Table 2) revealed in participants' explanations for their choices of personal and national heroes and in their choices of desired collective actions was aimed at identifying the types of action considered heroic from different (personal, national, desired) perspectives in the involved nationalities. Responses to the three questions were consistently sorted into the same set of thematic categories:

1. Type of action: (a) fight for something (e.g., "fought for his country"), (b) support for something (e.g., "She was who in all conditions stood up for me and for the whole family. She is who gives me directions in difficult situations still today"), (c) political act (e.g., "She has undertaken to carry out the British Referendum choice to leave the European Union against the wishes of her political party"), (d) creation of something (e.g., 


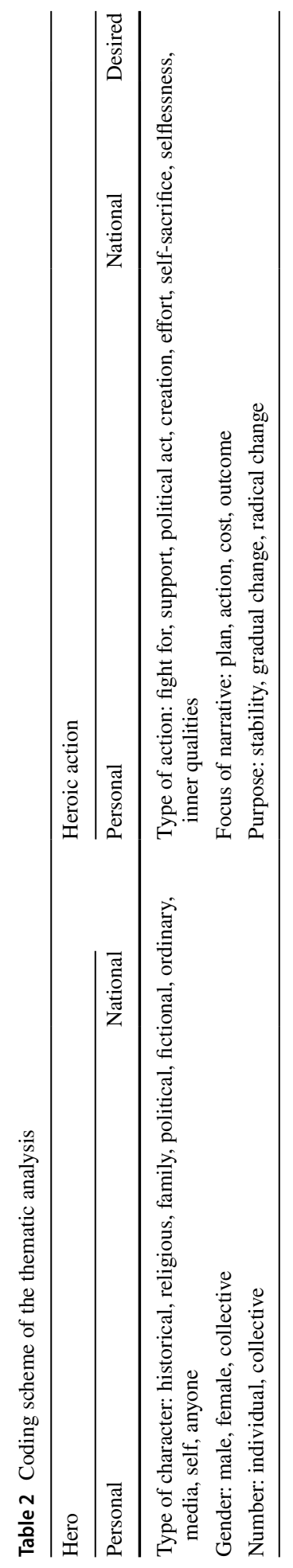


Table 3 Age related to the heroic choices at a personal and a national level

\begin{tabular}{|c|c|c|c|c|c|c|c|c|}
\hline & & \multicolumn{7}{|c|}{ Type of character } \\
\hline & & Political & Family & Religious & Historical & Ordinary & Fictional & No one \\
\hline Measure & Question & & & & & & & \\
\hline \multirow[t]{2}{*}{$\begin{array}{l}\text { Age } \\
M(S D)\end{array}$} & Personal & $\begin{array}{c}38.83 \\
(14.55)\end{array}$ & $\begin{array}{c}32.16 \\
(13.35)\end{array}$ & $\begin{array}{c}43.95 \\
(17.27)\end{array}$ & $\begin{array}{c}34.3 \\
(14.6)\end{array}$ & $\begin{array}{c}33.11 \\
(11.53)\end{array}$ & $\begin{array}{c}32.87 \\
(12.11)\end{array}$ & $\begin{array}{c}34.11 \\
(14.63)\end{array}$ \\
\hline & National & $\begin{array}{l}37.00 \\
(16.70)\end{array}$ & $\begin{array}{l}35.10 \\
(1.97)\end{array}$ & $\begin{array}{c}40.30 \\
(16.00)\end{array}$ & $\begin{array}{c}34.60 \\
(13.30)\end{array}$ & $\begin{array}{c}35.00 \\
(13.00)\end{array}$ & $\begin{array}{l}30.00 \\
(9.69)\end{array}$ & $\begin{array}{c}32.70 \\
(12.30)\end{array}$ \\
\hline
\end{tabular}

"he made simplicity brilliant and he was able to create"), (e) effort (e.g., "Because he built a very successful advertising agency for over 50 years with no college education and in troubled economic times"), (f) self-sacrifice (e.g., "He gave his all to make me and our family happy and successful, he worked hard and gave his life to his family") (g) selflessness (e.g., "She has not had an easy life and faces challenges every day, but remains positive, caring, and selfless"), (h) inner qualities (e.g., "For his self control and determination").

2. Focus of narrative: In this case, we coded the respondents to focus on the episodic structure of the heroic action. The narrative focus can be (a) on the plan of the hero (e.g., "for the purity of his motivation"), (b) focus on the action (e.g., "Cross the ocean to explore the unknown."), (c) focus on the cost of the action (e.g., "because she sacrificed her appearance and her lifestyle without being sure about the success"), (d) focus on the outcome (e.g., "Because risking his life he proved the Hungarian virtue in the space").

3. Purpose of the hero: we also distinguished according to the purpose attributed to the heroic action, if the hero's action is interpreted as to provide (a) stability (e.g., "Because he stood by the traditions, the old, customary practices, which are important to me as well."), (b) gradual change (e.g., "She devoted her time to helping people and preaching tolerance"), or (c) a radical change (e.g.,"Real revolution, to concretely change the status quo.").

\section{Results}

\section{The Choice of Heroic Figures}

The majority of both personal and national heroes were men $(52.88 \%$ and $54.03 \%$, respectively). The proportion of female personal heroes $(22.30 \%)$ was significantly larger than that of female national heroes (7.54\%). The remaining percentage are related to collective characters (e.g., healthcare workers).

For a personal hero, $27.43 \%$ of the overall sample chose a family member, while $18.64 \%$ chose a political actor. The third most frequent category was anyone $(10.26 \%)$. The most frequently chosen national heroes were political actors $(22.72 \%)$, anyone (22.30\%), historical Figs. (12.88\%), and ordinary people (11.52\%). 
Table 4 Percentage frequencies of the chosen figures among the different subsamples

\begin{tabular}{|c|c|c|c|c|c|c|c|c|}
\hline & & Political & Family & Religious & Historical & Ordinary & Fictional & No one \\
\hline Subsample & Question & & & & & & & \\
\hline \multirow[t]{2}{*}{ British } & Personal & 20.87 & 37.39 & $\mathrm{a}$ & $\mathrm{a}$ & $\mathrm{a}$ & a & a \\
\hline & National & 37.39 & $\mathrm{a}$ & $\mathrm{a}$ & a & a & a & a \\
\hline \multirow[t]{2}{*}{ French } & Personal & 17.5 & 16.88 & $\mathrm{a}$ & $\mathrm{a}$ & 10.63 & 21.25 & 12.5 \\
\hline & National & 11.25 & $\mathrm{a}$ & $\mathrm{a}$ & $\mathrm{a}$ & 11.88 & $\mathrm{a}$ & 20 \\
\hline \multirow[t]{2}{*}{ German } & Personal & $\mathrm{a}$ & 36.05 & $\mathrm{a}$ & $\mathrm{a}$ & 13.95 & $\mathrm{a}$ & 10.47 \\
\hline & National & 22.67 & $\mathrm{a}$ & $\mathrm{a}$ & $\mathrm{a}$ & 14.53 & $\mathrm{a}$ & 30.23 \\
\hline \multirow[t]{2}{*}{ Greek } & Personal & 28.3 & 16.98 & $\mathrm{a}$ & 24.53 & $\mathrm{a}$ & $\mathrm{a}$ & 11.32 \\
\hline & National & 22.64 & $\mathrm{a}$ & $\mathrm{a}$ & 38.86 & $\mathrm{a}$ & $\mathrm{a}$ & 18.87 \\
\hline \multirow[t]{2}{*}{ Hungarian } & Personal & a & 35.05 & 12.15 & $\mathrm{a}$ & $\mathrm{a}$ & $\mathrm{a}$ & 10.28 \\
\hline & National & 15.42 & $\mathrm{a}$ & $\mathrm{a}$ & 21.96 & 14.49 & $\mathrm{a}$ & 23.36 \\
\hline \multirow[t]{2}{*}{ Italian } & Personal & 24.27 & 13.59 & $\mathrm{a}$ & $\mathrm{a}$ & 10.68 & $\mathrm{a}$ & 16.5 \\
\hline & National & 19.42 & $\mathrm{a}$ & $\mathrm{a}$ & $\mathrm{a}$ & 11.65 & $\mathrm{a}$ & 34.95 \\
\hline \multirow[t]{2}{*}{ Turkish } & Personal & 51.76 & 27.06 & $\mathrm{a}$ & $\mathrm{a}$ & $\mathrm{a}$ & $\mathrm{a}$ & $\mathrm{a}$ \\
\hline & National & 47.06 & $\mathrm{a}$ & $\mathrm{a}$ & $\mathrm{a}$ & 10.59 & $\mathrm{a}$ & 14.12 \\
\hline
\end{tabular}

${ }^{\text {a }}$ Relative frequency lower than $10 \%$

Significant differences were found with one-way ANOVA in mean age (Table 3) across different types of personal heroes $(F(14,794)=3.218 ; p=0.000)$. Those who chose religious figures for a personal hero were significantly older $(M=43.95)$ than those who chose family members $(M=32.16$; post hoc Tukey HSD $p=0,000)$, fictional characters $(M=32.87$; post hoc Tukey HSD $p=0,009)$, ordinary people $(M=33.11$; post hoc Tukey HSD $p=0.015)$, or no one $(M=34.11$; post hoc Tukey HSD $p=0.033)$. Those who chose political actors $(M=38.83)$ were older than those who chose family members $(M=32.16)$ (post hoc Tukey HSD $p=0.000$ ). No age differences were found related to the choice of national hero.

The frequency distributions of various types of character revealed that all subsamples showed one of the highest preferences (between the 3 most chosen categories) for political actors both as personal and as national heroes (only Hungarians and Germans did not choose political actors as personal hero) (see Table 4). This preference was the most pronounced among Turkish participants, about half of them named a political actor both at the national (47\%) and personal level (52\%). As members of their respective national groups, participants tended to name popular public figures, anchoring themselves to political representatives and their ideologies (e.g., Margaret Thatcher, Barack Obama, Angela Merkel, Viktor Orbán, Marie Curie, Roger Federer).

At the personal level, family members (e.g., father, mother, aunt) were chosen by a relatively high proportion of participants in each subsample; among British, German, and Hungarian participants, this category was the most relevant. Historical figures were named in the Greek and Hungarian subsamples, and only Greek participants chose such figures the more as a personal hero too. German participants showed the highest (within group) preference for family members at the personal level and at both the personal and national levels this subsample chose the more ordinary people. Ordinary people were also frequently chosen as national heroes by Hungarian participants, who showed the highest preference among the subsamples for religious figures as personal heroes. Fictional figures were 
chosen as personal heroes by a considerable proportion of French participants. Among Italian participants, no choice was the highest both for personal and national hero. At the level of within-group choices, German, Hungarian, and French participants mostly preferred to not choose a national hero.

According to the gender of the chosen personal heroes, Greek and Turkish participants show the highest percentage of male figure choices ( $92.58 \%$ and $76.47 \%$ ), other subgroups are all around 50\%, Hungarian choose the less male heroes (43.2\%). The most female personal heroes are chosen among British and Hungarian participants (41.96\% and $31.07 \%$ ), while only the $7.41 \%$ of Greeks and $8.24 \%$ of Turkish participants choose women. Collective characters are chosen by $21.19 \%$ of the whole sample, with Italians who choose the most (30.39\%) and Greeks who do not choose collective heroes (0\%) (Fig. 1).

According to the gender of the chosen national heroes, both the preference of "lone" male heroes (63.18\%) and collective characters (27.97\%) increased for the whole population. The pattern of the different subpopulations is similar to the personal hero choice. Greeks (98.67\%) and Turkish (70.59\%) choose the most male figures, while in this case Italians the least (51.96\%). British (18.45\%), German (13.14\%), French (12.59\%) respondents choose above average $(8.87 \%)$ female heroes. Italians choose the most collective characters (45.10\%) and Greeks did not choose collective characters (0\%) (Fig. 2).

The choice of collective characters (e.g., firemen, doctors, nurses) increases from personal heroes $(21.19 \%)$ to their choice as national heroes $(27.95 \%$,). Italians are those who choose them more at both levels, but nearly 1/3 of the German, Hungarian, French subsamples also prefer collectivities as heroes, while Greeks did not consider them as heroes at all $(0 \%)$.

\section{Heroic Actions: Types of Action}

Of the overall sample, $22.58 \%$ explained their choices of personal heroes by an inner quality attributed to them (e.g., courage, intelligence, values, selflessness, honesty, strength), $13.09 \%$ by the support they provided for someone, $12.15 \%$ by their willingness to fight for

THE GENDER OF PERSONAL HEROES IN THE DIFFERENT SUBSAMPLES (\%)

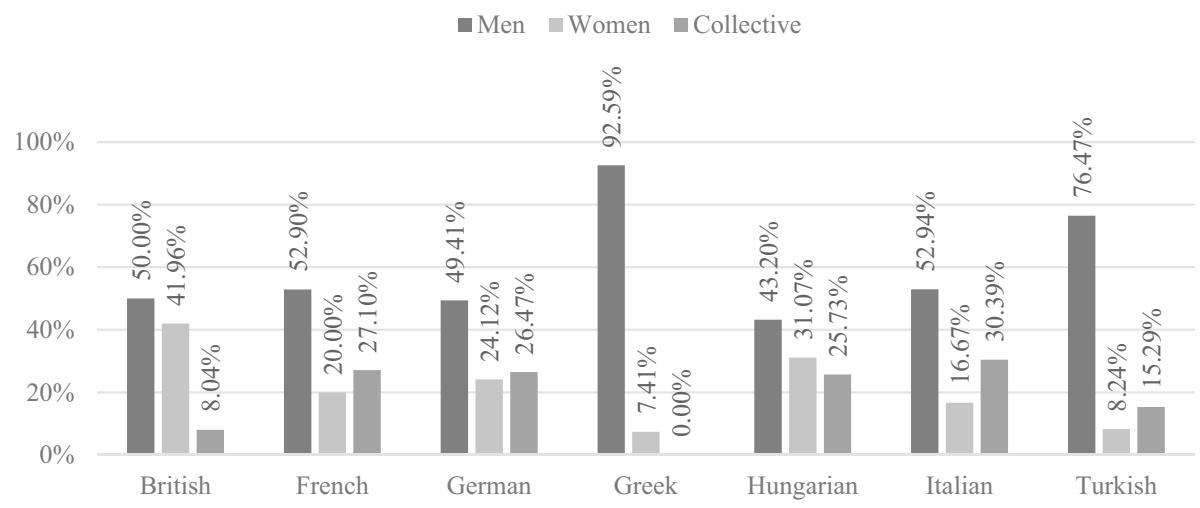

Fig. 1 Gender of personal heroes in the different subsamples (\%) 


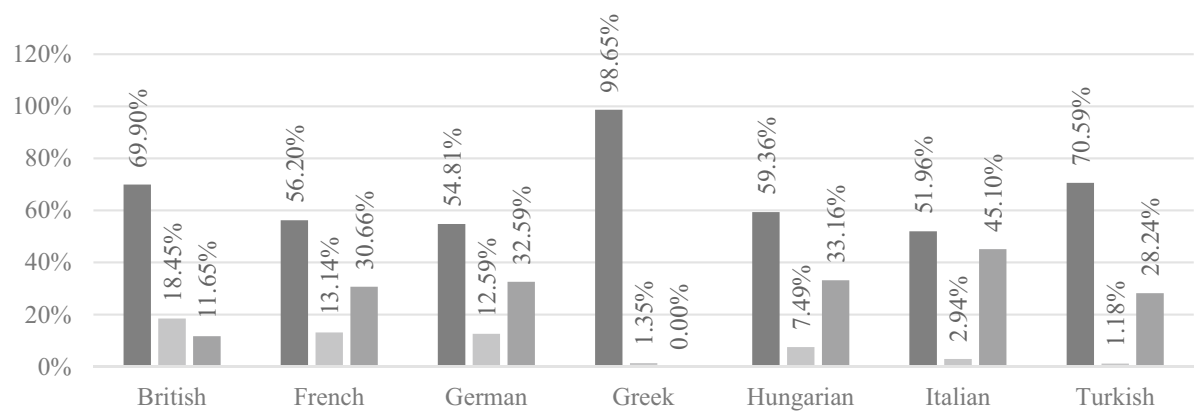

Fig. 2 Gender of national heroes in the different subsamples (\%)

a cause, and $11.62 \%$ by the efforts they made. A relatively high proportion of participants (18.53\%) did not explain their choices (Fig. 3).

At the national level, a high proportion $(31.62 \%)$ of the overall sample chose not to explain their choices. Those who gave an explanation primarily referred to their national heroes' inner qualities (16.07\%), political acts (12.61\%), or willingness to fight for a cause (12.18\%) (Fig. 3).

Regarding the desired actions chosen in a national context, the highest proportions of participants in the overall sample chose political actions (28.99\%), support (17.02\%), and fight $(15.44 \%)$. These results suggest that many people in the involved nationalities have a need for political change and mutual support, and they or someone else should fight for the desired change (Fig. 3).

Table 5 shows the differences in the explanations between the different subsamples. Apart from the German subsample, fight appears at least as a desired action in all subsamples. Participants in most subsamples chose political acts at the desired level, some of them at the national and personal level too, Italians, French, and Hungarians are those

HEROIC ACTION EXPLANATIONS FOR THE WHOLE SAMPLE (\%)

- Personal National $\square$ Desired

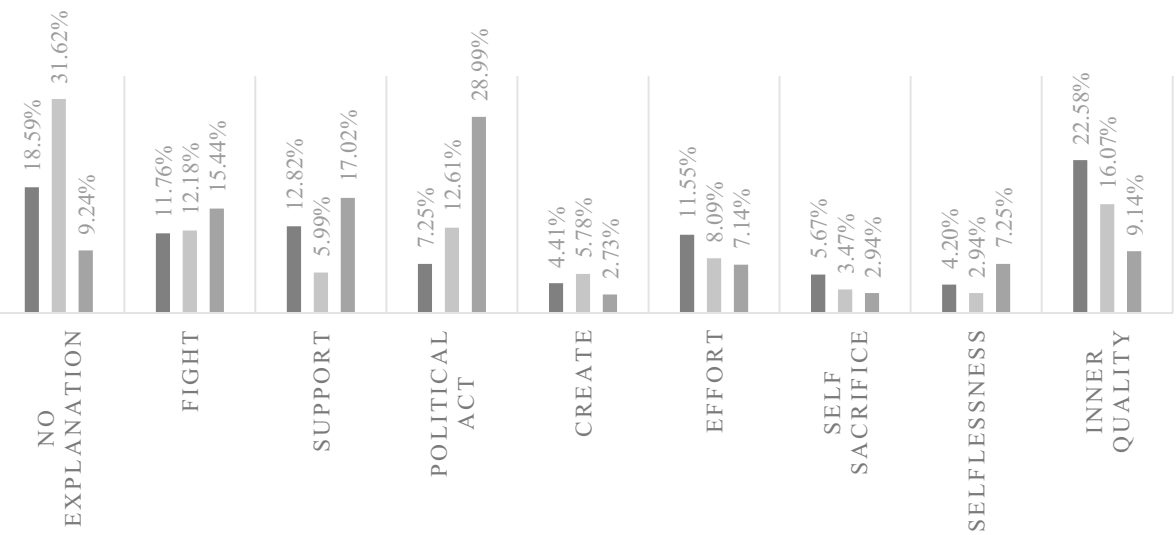

Fig. 3 Heroic action explanation for the whole sample (\%) 


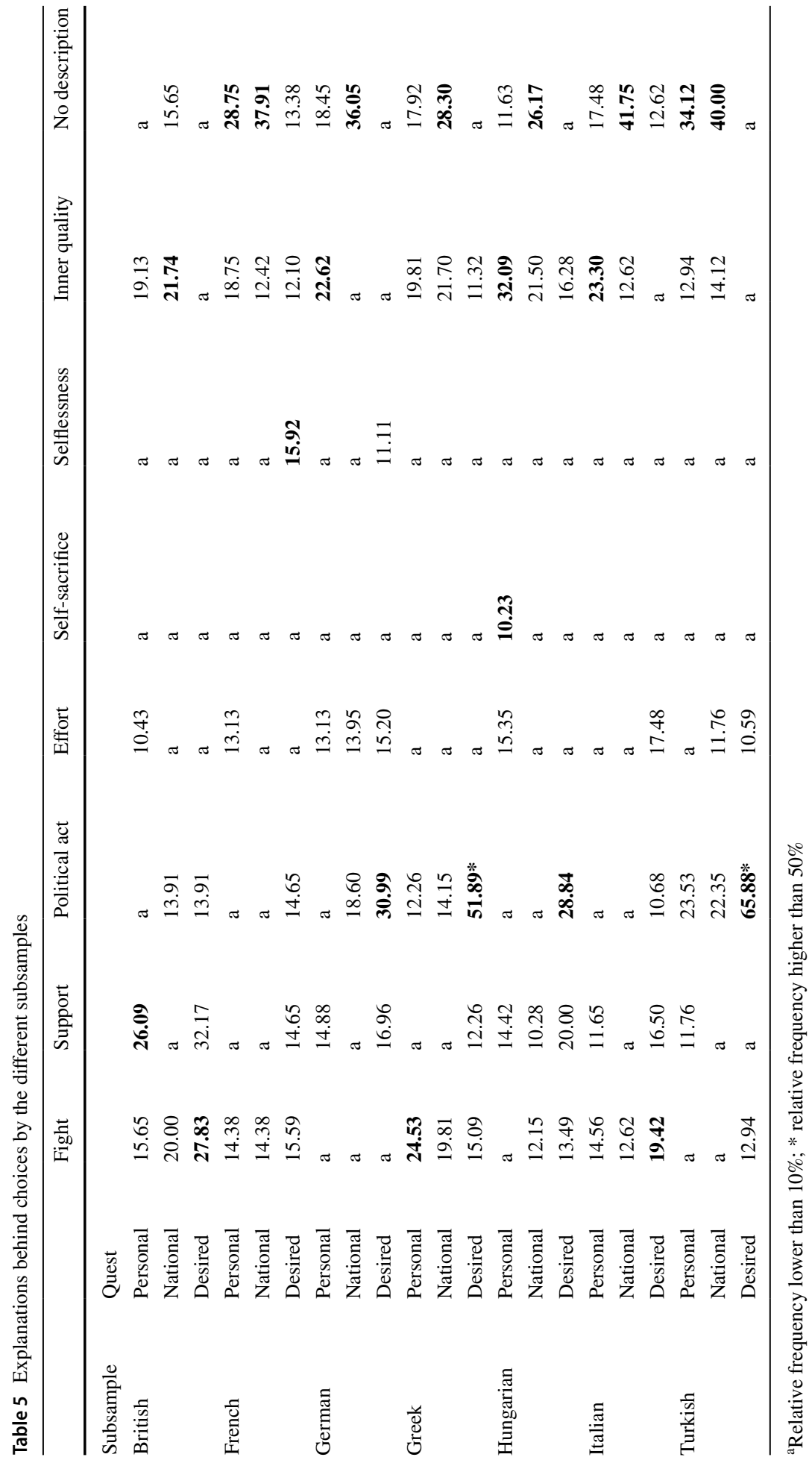


Table 6 The purpose of heroic actions (\% within subsamples)

\begin{tabular}{llllr}
\hline & & Stability & Gradual change & Radical change \\
\hline Subsample & Question & & & \\
British & Personal & 27.59 & $\mathbf{5 5 . 1 7}$ & 17.24 \\
& National & 16.39 & $\mathbf{7 5 . 4 1}$ & 8.20 \\
& Desired & 13.73 & $\mathbf{6 8 . 6 3}$ & 17.65 \\
French & Personal & 30.86 & $\mathbf{3 7 . 0 4}$ & 32.10 \\
& National & 19.12 & $\mathbf{5 5 . 8 8}$ & 25 \\
& Desired & 14.6 & 40.88 & $\mathbf{4 4 . 5 3}$ \\
German & Personal & $\mathbf{7 2 . 1 3}$ & 24.59 & 3.28 \\
& National & $\mathbf{5 5 . 5 6}$ & 37.37 & 7.07 \\
\multirow{5}{*}{ Greek } & Desired & $\mathbf{4 8 . 8 9}$ & 46.67 & 4.44 \\
& Personal & 22.06 & 33.82 & $\mathbf{4 4 . 1 2}$ \\
& National & 14.29 & 28.57 & $\mathbf{5 7 . 1 4}$ \\
Hungarian & Desired & 5.68 & 23.86 & $\mathbf{7 0 . 4 5}$ \\
& Personal & $\mathbf{5 2 . 2 9}$ & 33.33 & 14.38 \\
& National & 28.68 & $\mathbf{3 8 . 9 7}$ & $\mathbf{3 2 . 3 5}$ \\
& Desired & 20.21 & $\mathbf{4 2 . 0 2}$ & $\mathbf{3 7 . 7 7}$ \\
Italian & Personal & 33.56 & 33.33 & 31.11 \\
& National & 13.95 & $\mathbf{6 5 . 1 2}$ & 20.93 \\
& Desired & 33.72 & $\mathbf{3 8 . 3 7}$ & 27.91 \\
Turkish & Personal & 17.65 & 23.53 & $\mathbf{5 8 . 5 2}$ \\
& National & 23.26 & 30.23 & $\mathbf{4 6 . 5 1}$ \\
& Desired & 0 & 39.24 & $\mathbf{6 0 . 7 6}$ \\
\hline \multirow{6}{*}{. } & & &
\end{tabular}

who choose the least and only at the desired action level. Support also appeared in all subsamples, among Greeks and French only at a desired level, and among Turkish participants only at the personal level. Finally, only Hungarians referred to self-sacrifice (when explaining their choices of personal heroes) Table 6.

\section{Heroic Actions: Narrative Focus}

The explanations for the choices of personal and national heroes and the descriptions of the desired actions were more frequently focused on the heroic action itself and on the outcome rather than on the plan or on the cost to pay. However, this focus showed differences across the three levels. The descriptions of the desired heroic actions were the most action-oriented, while the importance of the sacrifice and the outcome was most pronounced in the personal heroic stories, and these stories were the least frequently focused on the plan (Fig. 4).

Participants focusing on different components of the personal heroic story significantly differed in age $(F(3,599)=3.802, p=0.010)$. Those who focused on the plan were significantly older $(M=38.213)$ than those who focused on the sacrifice $(M=30.943)$ (post hoc Tukey HSD $p=0.008)$.

A comparison of the subsamples for the narrative focus of the personal heroic story revealed that the British sample was mainly plan- and action-oriented. French, German, 


\section{NARRATIVE FOCUS OF THE EXPLANATION OF HEROIC CHOICES} (\% WITHIN LEVELS)

- Personal National $\quad$ Desired

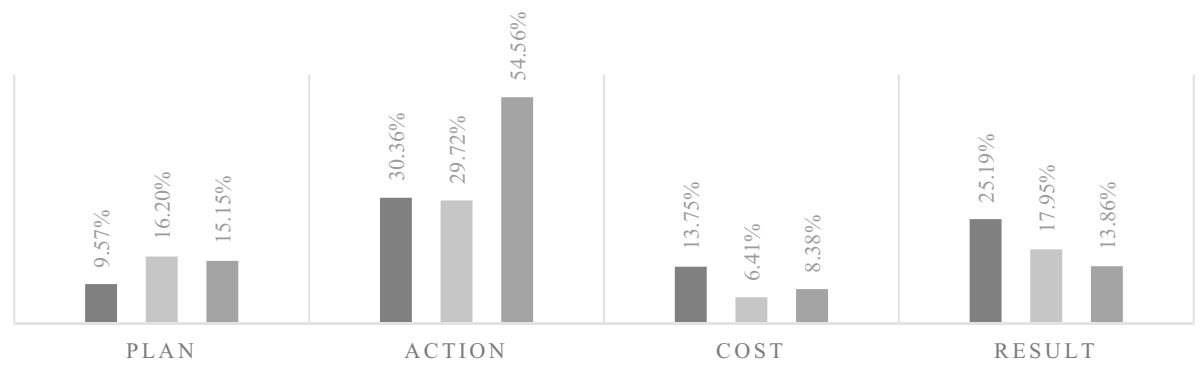

Fig. 4 Narrative focus of the heroic actions in the overall sample

Italian, Turkish samples were action- and outcome-oriented, while Hungarians, and less the Greeks sacrifice and outcome oriented (Fig. 5).

Regarding the national heroic story (Fig. 6), British, French, Italian, and Turkish samples appear all as plan- and action-oriented. Germans as before and Hungarians focus mainly on action and outcome, while Greeks focus mainly only on action. Still, Hungarians are those who focus the most on the cost as well.

There were no significant differences in the narrative focus of the national heroic story concerning age.

Regarding the desired heroic story, the Turkish and the Italian subsamples placed focus on plan and action; Germans as before on action and outcome; British, Hungarians, and Greeks mainly only on the action, while French surprisingly on the sacrifice and the action (Fig. 7).

Participants focusing on different components of the desired heroic story show tendencial differences in age $(F(3,725)=2.634, p=0.049)$. Those who focus on the action of the desired heroic story are older $(M=35.855)$ than those who are focusing on the sacrifice $(M=30.65)$ (post hoc Tukey HSD $p=0.031)$.

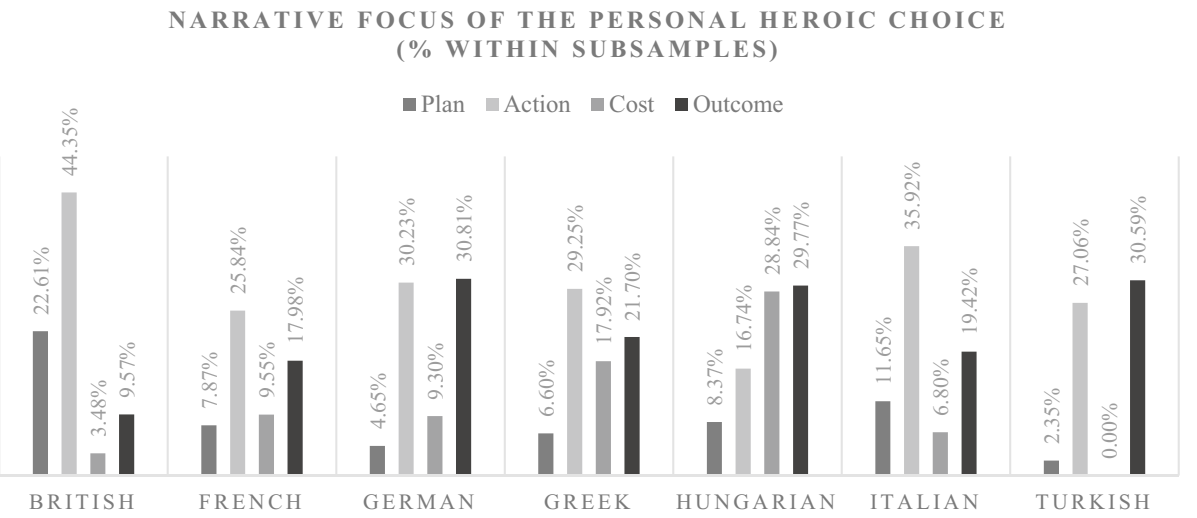

Fig. 5 Narrative focus by subsamples concerning the personal heroic choice 
NARRATIVE FOCUS BY SUBSAMPLES CONCERNING THE

NATIONAL HEROIC CHOICE(\% WITHIN SUBSAMPLES)

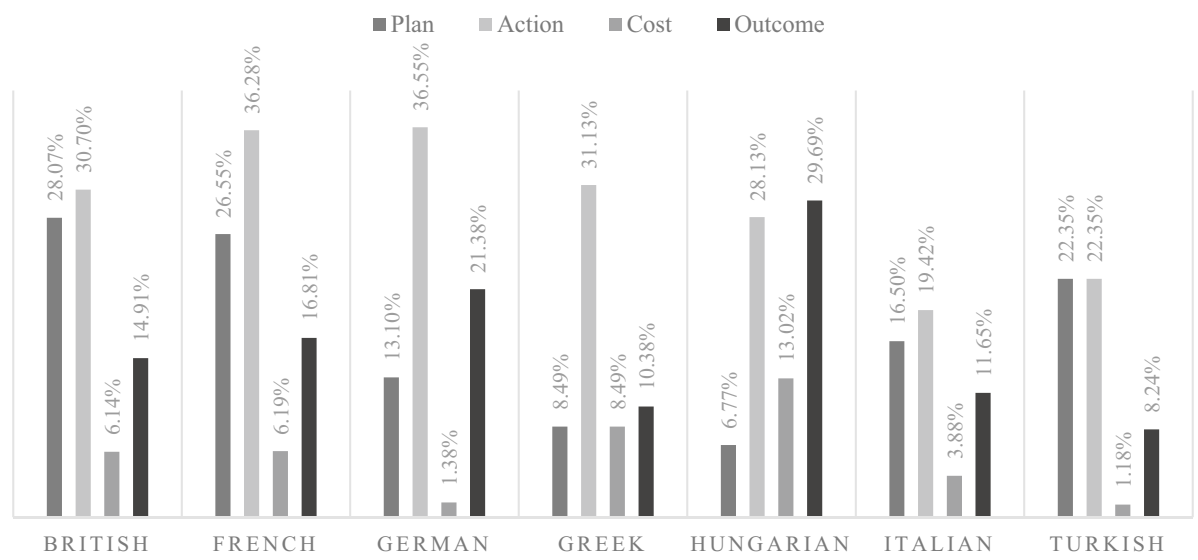

Fig. 6 Narrative focus by subsamples concerning the national heroic choice

\section{Heroic Action: Purpose of the Hero}

The purpose of the heroic actions showed differences across the personal, national, and desired levels. The purpose most frequently assigned to personal heroes was maintaining stability $(30.47 \%)$, while national heroes were primarily associated with achieving gradual change (27.43\%), and the most important desired actions included both gradual (37.83\%) and radical change (31.08\%).

Participants assigning different purposes to personal heroic actions (i.e., stability, gradual change, or radical change) showed significant differences in age $(F(3,766)=3.911$, $p=0.009)$. Those who expressed a need for stability were significantly younger $(M=32.159)$ than those who believed that heroic actions should serve either gradual change $(M=35.331)$ or radical change $(M=35.750)$.

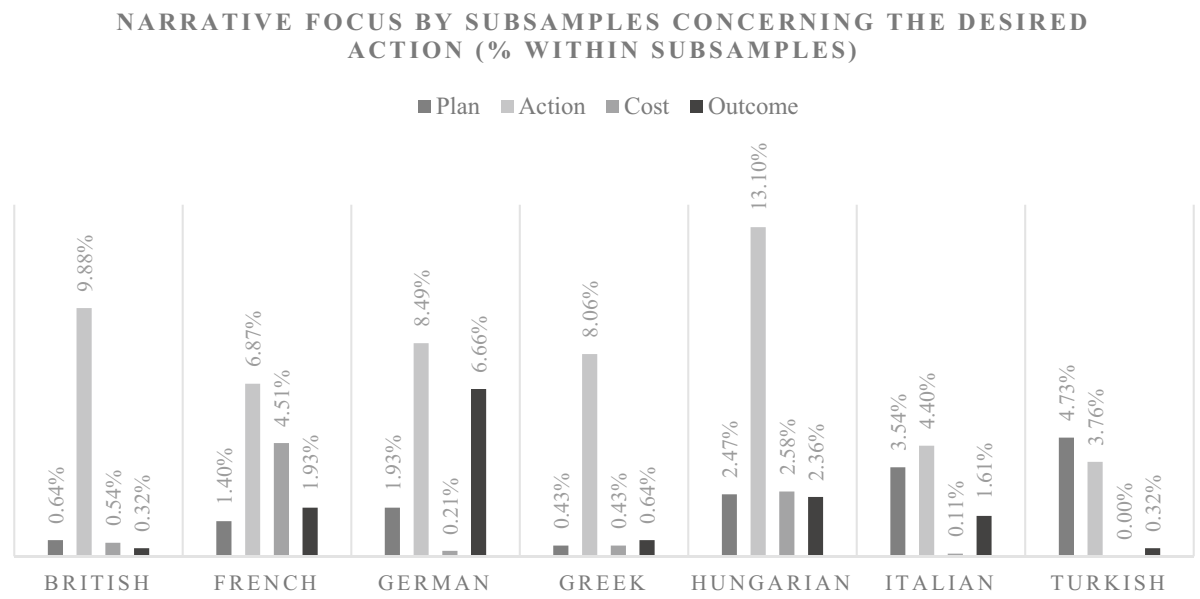

Fig. 7 Narrative focus by subsamples concerning the desired action 


\section{THE OBJECT OF HEROIC ACTION AT DIFFERENT LEVELS} (\% WITHIN LEVELS)

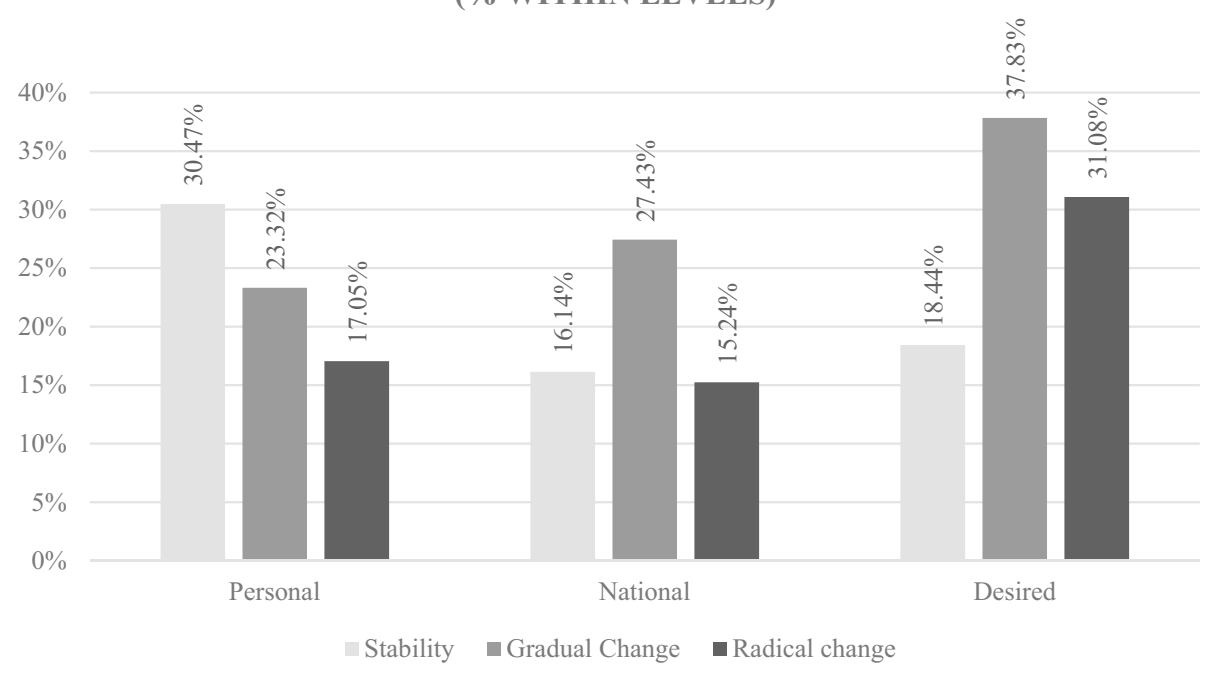

Fig. 8 Relative frequencies of the purposes of personal, national, and desired heroic actions

The subsamples showed different tendencies in their preferences for different purposes of heroic actions. German participants primarily endorsed heroic actions aimed at maintaining stability, while British participants preferred actions for gradual change. The French subsamples showed a heterogeneous picture in terms of purposes: no particular preference was found at the personal level, while the most preferred purpose was gradual change at the national level, and gradual and radical change at the desired level. A similar pattern was shown by the Italian subsample, apart from the desired actions, which they primarily associated with gradual rather than radical change. Hungarian participants most frequently chose stability at the personal level, while their responses pointed out gradual and radical change both at the national and desired level. Greek and Turkish participants consistently preferred radical change at each level (Fig. 8).

\section{Discussion}

As a hero, a value-based, radically ambivalent concept that at the same time objectifies and personifies power managed good and bad in present polarized societies and contextualize into potential (in)action (Boulanger, 2019), their choice and the explanation of that choice are not an easy task (high rate of no choice). However, according to the choices and explanations made by our sample, we can find prototypically the contemporary lone moral man acting on the private (family members) and public sphere (political actors) of the individuals. While individuals have experiences of morally judged women only in the private sphere, the public sphere beside political actors, offers as valorous the institutionalized (Assman, 2011) remote past (historical figures) and the everyday no name heroes (ordinary people), valuing the exceptional and the ordinary in a dialogical frame. Another similar dialogical frame is captured at the private sphere of the imagined morality; the generational gap between the sacred (religious figures) and the fictive. There is also a 
changing intensity and broadness of moral commitment with age, a result that could be hypothetically explained as a developmental shift or a result of generational gap. While in comparison, elders choose with the purpose of representing change from a more wider public sphere (religion and the political arena) and focus on plan and action, youngsters seeking for stability do not choose, choose ordinary people or the narrow family for moral compass and focus on the sacrifice of the heroic.

More the personal than the public, but both spheres (Jovchelovitch, 1995) offer the naturalization of the hero similarly to the mainstream theoretical definitions, which means at least two implicit psychological assumptions: the exceptionality of certain individuals (inner qualities) and a supreme and constant value-system according to which the exceptionality can be defined (Moscovici, 1993).

The personal sphere offers support, advocation (fighting for), motivation (efforts) creating that constraining (costs), and supporting context of that "bounded indeterminacy" of transition (Valsiner, 1987) from the present (action) to the next future (results); however, the aim seems to be mainly to maintain stability. In contrast, in the public sphere, change is a request (both at the national existent and national desired level), embedded in political acts, fight, and solidarity (support). Heroes in the public sphere are people in action. While the present public sphere offers actions aimed at gradual change, the request regarding the next future is more radical.

As the inherent ambivalence of the hero belongs to the changing intersection between the concrete action and the competing values of a given socio-cultural context, we can infer from the patterns of data differences and similarities (Fig. 9). The choices of the British subsample clearly separate private (heroes: family members, heroic actions: support) and public sphere (heroes: political actors, heroic actions: inner qualities and fight) of morality. Both are activated for a gradual change, not only the action (at each level), but also the motivation of the chosen hero (personal and national) is viewed as part of the heroic act. The choices of the French subsample are much more heterogeneous and reflect the

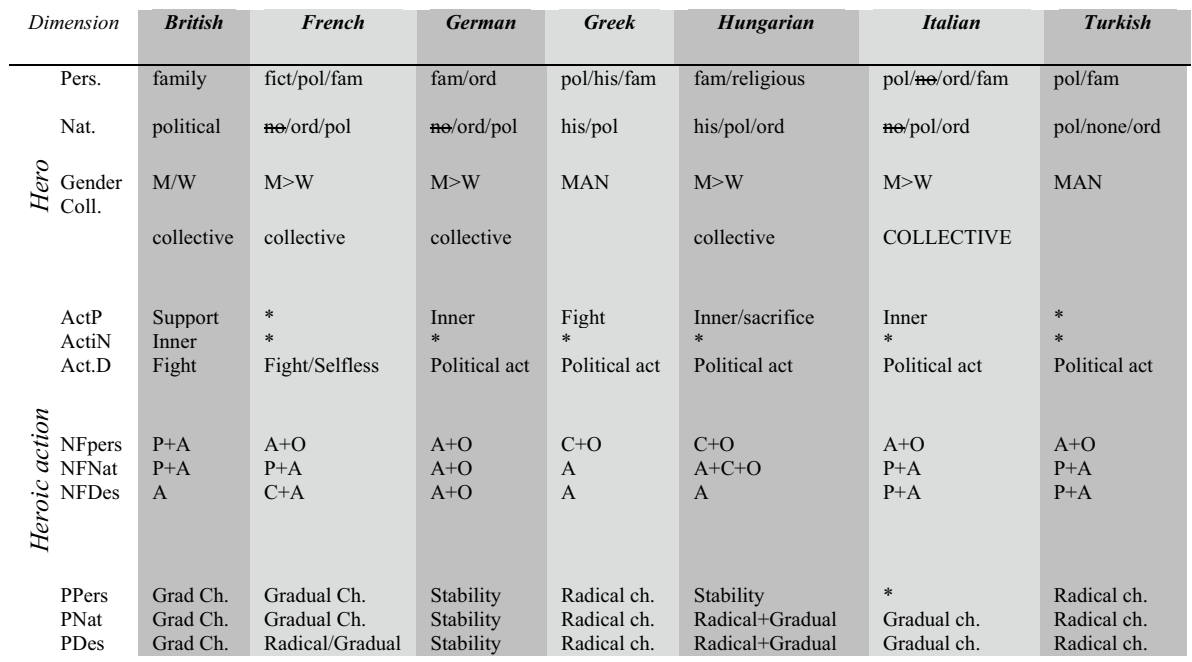

Fig. 9 Patternsof the subsamples 
above mentioned dialogical contrasts, the extraordinary (Political actors, fictive characters) versus the ordinary (ordinary people, family members), or between the imagined (fictive) and the real (political). While the purpose is change at each level, the cognitive polyphasia characterizes more the present (heterogeneity of the narrative focus, actions, personal, and national heroic choices) than the potential next future based on activating solidarity (because potential actions of selflessness and fight justified by a narrative of sacrifice and action). The choices of the Italian subsample reflect quite similar patterns to the French, but with a less visible next future. The German subsample seems very pragmatic to maintain stability, supported by the schematic narrative focus on action and outcome. They separate the private (family members for their inner qualities as personal heroes) and the public sphere (acting political actors) and value the efforts of the ordinary men (collective characters). Greek and Turkish subsamples' hero is a lone man (from the family or the political arena) seeking for radical change and the desired action is political. However, the dialogical nature of the public sphere differs between the two subsamples: for the Turkish anchored to present moral dilemmas political actors and ordinary men are in competition, and their motivation (plan) becomes important, Greeks anchoring is more stable between political actors and remote historical characters. While their personal choice fights, selfsacrifices (cost), and obtains results, their national choice just acts. At least, the specificity of the Hungarian subsample is the representation of the hero based on his/her sacrifice and paid costs and an anchor to remote past or religion. For their private choices, family members and religious figures are chosen the most; heroism is based on their inner quality and the presented sacrifice with the aim to maintain stability. For the public sphere (national and desired action), the purpose become change (gradual or radical), however in a chaotic field of competing extraordinary individuals from cultural (historical figures) to communicative memories (political figures) as well as ordinary people too, with their actions, exhibited sacrifices (cost) and obtained results (outcome). And then the next future: visualized as a change, imagined at a level of the political arena (political acts), somehow seems a resolution from the outside.

\section{Limitations}

Qualitative analysis of data asks for decisions to take by the researcher. The first decision we made was to make an explorative study about heroes. Contributing to the wide research paradigm on the effects of moral exemplars on intergroup relations, we used the story of a Hungarian hero saving Jewish lives to diminish today's prejudice and to take collective responsibility about past events, without success. Then, we understood that the hero is a hero for us, but not for our subjects. This is why we decided to explore what the hero could mean.

We asked a few simple open-ended questions to people of different contexts, to which they answered in a very heterogeneous way using their own concepts and words, their own representations about heroes and heroic actions. We used corpus construction of "signifiers of social life" (Bauer \& Aarts, 2000:23), focusing more on content analysis and less on the selection. In this way, the results are content-explorative and do not try to be representative of populations.

In our interpretation of data, we used the percentage of appearances of different thematic categories, to find out shared and differentiated patterns that could indicate potentialities in competing and sharing of content dimensions concerning heroes. The coded the- 
matic categories are just a few of the possible infinite, we coded other categories as well (from the more simple of holder's gender-hero's gender, to the applicable Schwartz values, if the action involve an object, the direction of the action, etc.), but we made a choice based on presentability with the analyzed dimensions more relevant to explore the potential of (heroic) actions in their context.

Funding Open access funding provided by University of Pécs. This research was funded by Grant No. K 119793 ("The influence of social identity on intergroup prejudice and collective action") of the National Research, Development and Innovation Office, Hungary (NKFIH).

\section{Declarations}

Consent to Participate Informed consent was obtained from all individual participants included in the study.

Conflict of Interest The authors have no conflicts of interest to declare that are relevant to the content of this article.

Open Access This article is licensed under a Creative Commons Attribution 4.0 International License, which permits use, sharing, adaptation, distribution and reproduction in any medium or format, as long as you give appropriate credit to the original author(s) and the source, provide a link to the Creative Commons licence, and indicate if changes were made. The images or other third party material in this article are included in the article's Creative Commons licence, unless indicated otherwise in a credit line to the material. If material is not included in the article's Creative Commons licence and your intended use is not permitted by statutory regulation or exceeds the permitted use, you will need to obtain permission directly from the copyright holder. To view a copy of this licence, visit http://creativecommons.org/licenses/by/4.0/.

\section{References}

Abric, J. C. (1996). Specific processes of social representations. Papers on Social Representations, 5(1), $77-80$.

Allison S. T., \& Goethals G. R. (2014). Now he belongs to the ages: The heroic leadership dynamic and deep narratives of greatness. In: Goethals G.R., Allison S.T., Kramer R.M., Messick D.M. (eds) Conceptions of Leadership. Jepson Studies in Leadership. Palgrave. 167-183. https://doi.org/10.1057/9781137472038_10

Anderson, J. R. (1991). The adaptive nature of human categorization. Psychological Review, 98(3), 409-429.

Assmann, J. (2011). Communicative and cultural memory. In Cultural memories. 15-27. Springer, Dordrecht. https://doi.org/10.1007/978-90-481-8945-8_2

Baldassarri, D., \& Park, B. (2020). Was there a culture war? Partisan polarization and secular trends in US public opinion. The Journal of Politics, 82(3), 809-827. https://doi.org/10.1086/707306

Baldwin, J. M. (1894). Imitation: A chapter in the natural history of consciousness. Mind. London. 3, 25-55.

Bauer, M. W. (2000). Classical content analysis: A review. Qualitative Researching with Text, Image and Sound, 131-151. https://doi.org/10.4135/9781849209731

Bauer, M. W., \& Aarts, B. (2000). Corpus construction: A principle for qualitative data collection. Qualitative researching with text, image and sound: A practical handbook, 19-37.

Batel, S. (2012). Commentary on re-presenting (and) cognitive polyphasia. Papers on Social Representations, 21(1), 10-1. ISSN 1021- 5573.

Bar-Tal, D., Chernyak-Hai, L., Schori, N., \& Gundar, A. (2009). A sense of self-perceived collective victimhood in intractable conflicts. International Review of the Red Cross, 91(874), 229-258. https://doi.org/ $10.1017 /$ S1816383109990221

Becker, S. W., \& Eagly, A. H. (2004). The heroism of women and men. American Psychologist, 59(3), 163-178. https://doi.org/10.1037/0003-066X.59.3.163

Bigazzi, S., \& Nencini, A. (2008). How evaluations construct identities: The psycholinguistic model of evaluation. Vincze, O. \& Bigazzi, S. (eds) Élmény, történet - a történetek élménye, UMK. 91-105. ISBN: 9789639609839 . 
Bigazzi, S., Serdült, S., \& Bokrétás, I. (2019). Empowerment of intergroup harmony and equity. In N. Balvin \& D. Christie (eds.) Peace psychology book series: Children and peace. From Research to Action. Cham, Springer Open. 119-137. https://doi.org/10.1007/978-3-030-22176-8_8

Billig, M. (1988). Social representation, objectification and anchoring: A rhetorical analysis. Social Behaviour, 3(1), 1-16.

Breakwell, G. M. (2001). Social representational constraints upon identity processes. In K. Deaux \& G. Philogène (Eds.), Representations of the social: Bridging theoretical traditions. 271-284. Blackwell Publishing. ISBN:9780631215332.

Boulanger, D. (2019). Aesthetic social representations and concrete dialogues across boundaries: Toward Intergenerational CHARACTERization in Culture \& Psychology, 26(2). https://doi.org/10.1177/1354067X19888198

Boulanger, D., \& Christensen, B. (2018). Social representations as social forms and aesthetic phenomena: Dialogue between Moscovici and Simmel. In L. Tateo (Ed.), An old melody in a new song: Aesthetics and psychology (pp. 181-182). New York: Springer. https://doi.org/10.1007/978-3-319-92339-0_11

Brown, D. (2011). The global financial crisis: Neo-liberalism, social democracy, and criminology in $\mathrm{M}$. Bosworth and C. Hoyle (eds.) What is criminology? Oxford Scholarship. https://doi.org/10.1093/ acprof:oso/9780199571826.003.0006

Bruner, J. (2004). Life as narrative. Social Research: An International Quarterly, 71(3), 691-710. https:// www.muse.jhu.edu/article/527352

Campbell, J. (2006). Polarization runs deep, even by yesterday's standards-Comment. in P. Nivola \& D. Brady (eds.). Red and blue nation? Characteristics and causes of America's polarized politics. Vol. 1, Washington, DC, and Stanford, CA: Brookings Insitution Press and Hoover Institution. 152-162. ISBN:9780815760849.

Čehajić-Clancy, S., \& Bilewicz, M. (2017). Fostering reconciliation through historical moral exemplars in a postconflict society. Peace and Conflict: Journal of Peace Psychology, 23(3), 288-296. https://doi.org/ $10.1037 /$ pac0000210

Charrue, J. M. (2005). La liberté comme idée, et comme réalité. Le Portique Retrieved August 25, 2021, from http://journals.openedition.org/leportique/654; https://doi.org/10.4000/leportique.654

Chomsky, N., \& Foucault, M. (2015). The Chomsky-Foucault debate: On human nature. The New Press. ISBN 978-1595581341.

Cohen, A. (1979). Political symbolism. Annual Review of Anthropology, 8(1), 87-113. https://doi.org/10. 1146/annurev.an.08.100179.000511

Collins, R. (1993). Emotional energy as the common denominator of rational action. Rationality and Society, 5(2), 203-230. https://doi.org/10.1177/1043463193005002005

Csikszentmihalyi, M., Condern, M., \& Lebuda, I. (2017). Deviant heroes and social heroism in everyday life: Activists and artists. In (eds.) S. T. Allison, G. R. Goethals \& R. M. Kramer Handbook of heroism and heroic leadership. Routledge. 249-261. ISBN. 978-1-138-91565-7.

Dogra, N. (2012). Representations of global poverty: Aid, development and international NGOs. Journal of Language and Politics, 15(4), 497-500. https://doi.org/10.1075/jlp.15.4.07jac

Down, I., \& Wilson, C. J. (2008). From permissive consensus to constraining dissensus: A polarizing union? Acta Politica, 43(1), 26-49. https://doi.org/10.1057/palgrave.ap.5500206

Duveen, G., \& Lloyd, B. (1986). The significance of social identities. British Journal of Social Psychology, 25(3), 219-230. https://doi.org/10.1111/j.2044-8309.1986.tb00728.x

Elcheroth, G., Doise, W., \& Reicher, S. (2011). On the knowledge of politics and the politics of knowledge: How a social representations approach helps us rethink the subject of political psychology. Political Psychology, 32(5), 729-758. https://doi.org/10.1111/j.1467-9221.2011.00834.x

Elcheroth, G. (2006). Individual-level and community-level effects of war trauma on social representations related to humanitarian law. European Journal of Social Psychology, 36(6), 907-930.

Elcheroth, G., \& Spini, D. (2011). Political violence, intergroup conflict, and ethnic categories. In D. BarTal (Ed.), Intergroup conflicts and their resolution: A social psychological perspective. Psychology Press. 175-194. ISBN 9781841697833.

Farley F. (2012). The real heroes of The Dark Knight. [Internet blog posted 27th July 2012, Retrieved August 26, 2021, from https://www.psychologytoday.com/intl/blog/the-peoples-professor/201207/ the-real-heroes-the-dark-knight

Farr, R. M. (1984). Les représentations sociales, in S. Moscovici (ed.) Psychologie Sociale. 379-389. Paris: PUF. ISBN: 978-2-13-063344-0.

Franco, Z., \& Zimbardo, P. (2006). The banality of heroism. Greater Good, 3(2), 30-35. Retrieved August 26, 2021, from https://greatergood.berkeley.edu/article/item/the_banality_of_heroism

Franco, Z. E., Blau, K., \& Zimbardo, P. G. (2011). Heroism: A conceptual analysis and differentiation between heroic action and altruism. Review of General Psychology, 15(2), 99-113. https://doi.org/10.1037/a0022672 
Gash, H., \& Conway, P. (1997). Images of heroes and heroines: How stable? Journal of Applied Developmental Psychology, 18(3), 349-372. https://doi.org/10.1016/S0193-3973(97)80005-6

Goethals, G. R., \& Allison, S. T. (2012). Making heroes: The construction of courage, competence, and virtue. Advances in Experimental Social Psychology, 46, 183-235. https://doi.org/10.1016/B978-0-12394281-4.00004-0

Graham, G. (1992). Liberalism and democracy. Journal of Applied Philosophy, 9(2), 149-160. Retrieved August 25, 2021, from http://www.jstor.org/stable/24353683 https://doi.org/10.1111/j.1468-5930. 1992.tb00305.x

Halmburger, A., Baumert, A., \& Schmitt, M. (2017). Everyday heroes: Determinants of moral courage. in (eds.) S. T. Allison, G. R. Goethals \& R. M. Kramer Handbook of heroism and heroic leadership. Routledge. 165-184. ISBN. 978-1-138-91565-7.

Hepburn, A. (2003). An introduction to critical social psychology. London: SAGE. pbk. 278. ISBN 0761962107.

Howarth C., Andreouli E., \& Kessi S. (2014). Social representations and the politics of participation. In: Nesbitt-Larking P., Kinnvall C., Capelos T., Dekker H. (Eds) The Palgrave handbook of global political psychology. Palgrave Studies in Political Psychology Series. Palgrave Macmillan. 19-38. https:// doi.org/10.1007/978-1-137-29118-9_2

Inglehart, R. (2000). Globalization and postmodern values. The Washington Quarterly, 23(1), 215-228. https://doi.org/10.1162/016366000560665

Inglehart-Welzel World Cultural Map. (2020). World Values Survey 7 [Provisional version]. Source: http:// www.worldvaluessurvey.org/

Jayawickreme, E., \& Di Stefano, P. (2012). How can we study heroism? Integrating persons, situations and communities. Political Psychology, 33(1), 165-178. https://doi.org/10.1111/j.1467-9221.2011.00861

Jovchelovitch, S. (1995). Social representations and public life: A study on the symbolic construction of public spaces in Brazil. PhD thesis, The London School of Economics and Political Science (LSE). http://etheses.lse.ac.uk/id/eprint/119

Jovchelovitch, S. (1997). Peripheral groups and the transformation of social representations: Queries on power and recognition. Social Psychology Review, 1(1), 16-26. ISSN 1369-7862.

Jovchelovitch, S. (2002). Re-thinking the diversity of knowledge: Cognitive polyphasia, belief and representation. Psychologie \& Societé, 5(1), 121-138.

Jovchelovitch, S. (2007). Knowledge in context: Representations, community and culture. Routledge.

Keczer, Z., File, B., Orosz, G., \& Zimbardo, P. G. (2016). Social representations of hero and everyday hero: A network study from representative samples. PLoS One, 11(8), e0159354. https://doi.org/10.1371/ journal.pone.0159354

Kinsella, E. L., Ritchie, T. D., \& Igou, E. R. (2017). Attributes and applications of heroes: A brief history of lay and academic perspectives. In (eds.) S. T. Allison, G. R. Goethals \& R. M. Kramer Handbook of Heroism and Heroic Leadership. Routledge 19-35. ISBN. 978-1-138-91565-7.

Kinsella, E. L., Ritchie, T. D., \& Igou, E. R. (2015). Zeroing in on heroes: A prototype analysis of hero features. Journal of Personality and Social Psychology, 108(1), 114-127. https://doi.org/10.1037/a0038463

Krippendorff, K. (1980). Validity in content analysis. In E. Mochmann (Ed.), Computerstrategien fur die kommunikationsanalyse (pp. 69-112). Frankfurt, Germany: Campus. Retrieved from http://repository. upenn.edu/asc_papers/291

Labov, W. (2010). Principles of linguistic change, volume III, cognitive and cultural factors. WileyBlackwell. ISBN: 978-1-405-11214-7.

László, J. (2013). Historical tales and national identity: An introduction to narrative social psychology. Routledge 978-0-415-70469-4; 978-0-415-70470-0.

László, J., Csertő, I., Fülöp, É., Ferenczhalmy, R., Hargitai, R., Lendvai, P., Peley, B., Polya, T., Szalai, K., Vincze, O., \&Ehmann, B. (2013). Narrative language as an expression of individual and group identity: The narrative categorical content analysis. SAGE Open 3. https://doi.org/10.1177/2158244013492084

Liu, J. H., \& László, J. (2007). A narrative theory of history and identity. Social identity, social representations, society and the individual. In G. Moloney \& I. Walker (Eds.). Social Representations and Identity: Content, Process and Power. Palgrave Macmillan. 85-107. ISBN 978-0-230-60918-1.

Liu, J. H., Goldstein-Hawes, R., Hilton, D., Huang, L. -L., Gastardo-Conaco, C., Dresler-Hawke, E., Pittolo, F., Hong, Y. -Y., Ward, C., Abraham, S., Kashima, Y., Kashima, E., Ohashi, M. M., Yuki, M., \& Hidaka, Y. (2005). Social Representations of events and people in world history across 12 cultures. Journal of Cross-Cultural Psychology, 36(2), 171-191. https://doi.org/10.1177/0022022104272900

Lloyd, B., \& Duveen, G. (1991). Expressing social gender identities in the first year of school. European Journal of Psychology of Education, 6(4), 437-447. https://doi.org/10.1007/BF03172776

Marková, I. (2011). L’influence et la dialogicité. Bulletin De Psychologie, 515, 391-398. https://doi.org/10. 3917/bupsy.515.0391 
Marková, I. (2013). Ethics in the theory of social representations. Papers on Social Representations, 22(1), 4-1.

Marková, I. (2017). The making of the theory of social representations. Cadernos de Pesquisa, 47(163), 358-375. ISSN 0100-1574.

Marks, D. F., \& Yardley, L. (2004). Content and thematic analysis. In Marks, D. F., \& Yardley, L. (Eds.), Research methods for clinical and health psychology. SAGE Publications, Ltd, 56-68. https://doi.org/ $10.4135 / 9781849209793$

McNeil-Willson, R., Gerrand, V., Scrinzi, F., \& Triandafyllidou, A. (2019). Polarisation, violent extremism and resilience in Europe today: An analytical framework. BRaVE Project. http://hdl.handle.net/1814/ 65664

Mintchev, N., \& Moore, H. L. (2019). Brexit's identity politics and the question of subjectivity. Psychoanalysis, Culture and Society, 24, 452-472. https://doi.org/10.1057/s41282-019-00139-3

Mols, F., \& Jetten, J. (2016). Explaining the appeal of populist right-wing parties in times of economic prosperity. Political Psychology, 37(2), 275-292. https://doi.org/10.1111/pops.12258

Moscovici, S. (2008). Psychoanalysis: Its image and its public (translated from French, original edition 1961). Polity Press.

Moscovici, S. (1984). The phenomenon of social representations. In R. Farr \& S. Moscovici (Eds.), Social representations. 3-69. Cambridge University Press.

Moscovici, S. (1988). Notes towards a description of Social Representations. in European Journal of Social Psychology. 18(3), 211-250. https://doi.org/10.1002/ejsp.2420180303

Moscovici, S. (1993). Toward a social psychology of science. Journal for the Theory of Social Behaviour, 23(4), 343-374. https://doi.org/10.1111/j.1468-5914.1993.tb00540.x

Mudde, C. (2004). The populist zeitgeist. Government and Opposition, 39(4), 542-563. https://doi.org/10. 1111/j.1477-7053.2004.00135.x

Murray, M. (2017). Narrative social psychology. In The Palgrave handbook of critical social psychology. Palgrave Macmillan, London. 185-204. ISBN 978-1-137-51018-1.

Nagy, C. I. (2019). Collective actions in Europe: A comparative, economic and transsystemic analysis Springer Nature. 122. https://doi.org/10.1007/978-3-030-24222-0

Reicher, S., \& Hopkins, N. (2001). Psychology and the end of history: A critique and a proposal for the psychology of social categorization. Political Psychology, 22(2), 383-407. https://doi.org/10.1111/0162895X.00246

Rimé, B., Bouchat, P., Klein, O., \& Licata, L. (2015). When collective memories of victimhood fade: Generational evolution of intergroup attitudes and political aspirations in Belgium. European Journal of Social Psychology, 45(4), 515-532. https://doi.org/10.1002/ejsp.2104

Rogoff, B. (2003). The cultural nature of human development. Oxford university press. ISBN-10: 0195131339.

Rose, D., Efraim, D., Gervais, M. C., Joffe, H., Jovchelovitch, S., \& Morant, N. (1995). Questioning consensus in social representation theory. Papers on social representations, 4, 150-176. https://www.researchgate.net/ deref/http\%3A\%2F\%2Fwww.psr.jku.at\%2FPSR1995\%2F4_1995Rose.pdf

Schwartz, S. H. (2012). An overview of the Schwartz theory of basic values. Online Readings in Psychology and Culture, 2(1). https://doi.org/10.9707/2307-0919.1116

Smith, N., \& Joffe, H. (2013). How the public engages with global warming: A social representations approach. Public Understanding of Science, 22(1), 16-32. https://doi.org/10.1177/0963662512440913

Staerklé, C. (2011). Back to new roots: Societal psychology and social representations. In Pires Valentim, J. (Ed.), Societal approaches in social psychology, 81-106. Peter Lang International Academic Publishers. https://doi.org/10.3726/978-3-0351-0350-2

Staerklé, C. (2013). The true citizen: Social order and intergroup antagonisms in political lay thinking. Papers on Social Representations, 22(1), 1-1.

Staerklé, C., \& Green, E. G. T. (2018). Right-wing populism as a social representation: A comparison across four European countries. Journal of Community and Applied Social Psychology, 28, 430-445. https://doi.org/10.1002/casp.2369

Tajfel, H. (1981). Human groups and social categories: Studies in social psychology. Cambridge University Press. ISBN 0521228395.

Tateo, L., \& Valsiner, J. (2015). Time breath of psychological theories: A meta-theoretical focus. Review of General Psychology, 19(3), 357-364. https://doi.org/10.1037/gpr0000035

Tsatsanis, E., Teperoglou, E., \& Seriatos, A. (2020). Two-partyism reloaded: Polarisation, negative partisanship, and the return of the left-right divide in the Greek elections of 2019. South European Society and Politics, 1-30. https://doi.org/10.1080/13608746.2020.1855798

Touraine, A. (1985). An introduction to the Study of social movement. Social Research, 52(4), $749-787$.

Turner, B., \& Hamilton, P. (Eds). (1994). Citizenship: Critical concepts. Routledge. ISBN 0415102464. 
Valsiner, J. (1987). Culture and the development of children's action: A cultural-historical theory of developmental psychology. John Wiley \& Sons.

Valsiner, J., \& van der Veer, R. (1993). The encoding of distance: The concept of the 'zone of proximal development' and its interpretations. in R.R. Cocking \& K. A. Renninger (eds.) The development and meaning of psychological distance LEA, 35:62.

Valsiner, J. (1997). Bounded indeterminacy in discourse processes. in C. Coll \& D. Edwards (Eds.) Teaching, learning and classroom discourse: Approach to the study of educational discourse, Fundación Infancia y Aprendizaje, 23-32.

Vossen, K. (2010). Populism in the Netherlands after Fortuyn: Rita Verdonk and Geert Wilders compared. Perspectives on European Politics and Society, 11(1), 22-38. https://doi.org/10.1080/15705850903553521

Vygolsky, L. S. (1933/1984). Sobranie sochinenii. Vol. 4. Detskaia psikhologia Moscow: Pedagogika.

Wagner, W. (1998). Social representations and beyond; Brute facts, symbolic coping and domesticated worlds. Culture \& Psychology, 4, 297-329. https://doi.org/10.1177/1354067X9800400302

Yadav, R. C. (2015). Role of female workforce participation in development of India. International Journal of Advanced Research, 3(8), 591-595. ISSN 2320-5407.

Zimbardo, P. (2008). The Lucifer effect. Random House Trade. ISBN 9780812974447.

Publisher's Note Springer Nature remains neutral with regard to jurisdictional claims in published maps and institutional affiliations. 